\title{
Technical Advance: Surface plasmon resonance-based analysis of CXCL12 binding using immobilized lentiviral particles
}

\author{
Beatriz Vega, * Laura Martínez Muño,* Borja L. Holgado, * Pilar Lucas, * \\ J. M. Rodríguez-Frade, ${ }^{*}$ Ana Calle, ${ }^{\dagger} J$. L. Rodríguez-Fernández, ${ }^{\ddagger}$ Laura M. Lechuga, ${ }^{\S}$ \\ José F. Rodríguez," Ricardo Gutiérrez-Gallego," and Mario Mellado*,1 \\ *Department of Immunology and Oncology, Centro Nacional de Biotecnología/Consejo Superior de Investigaciones \\ Cientificas, Campus de Cantoblanco, Madrid, Spain; 'IMM-Instituto de Microelectrónica de Madrid/Consejo Superior de \\ Investigaciones Cientificas, Madrid, Spain; Centros de ${ }^{\ddagger}$ Investigaciones Biológicas and ${ }^{\S}$ de Investigación en Nanociencia y \\ Nanotecnologia (CIN2)/Consejo Superior de Investigaciones Cientificas, Campus UAB Bellaterra, Barcelona, Spain; "CIBER- \\ BBN, Department of Molecular and Cellular Biology, Centro Nacional de Biotecnología/Consejo Superior de Investigaciones \\ Cientificas, Barcelona, Spain; and "Bioanalysis Group, Neuropsychopharmacology Program, IMIM-Hospital del Mar and \\ Department of Experimental and Health Sciences, University Pompeu Fabra (UPF), Barcelona Biomedical Research Park
} (PRBB), Barcelona, Spain

RECEIVED OCTOBER 18, 2010; REVISED APRIL 26, 2011; ACCEPTED APRIL 28, 2011. DOI: 10.1189/jlb.1010-565

\begin{abstract}
Use of SPR-based biosensors is an established method for measuring molecular interactions. Their application to the study of GPCRs is nonetheless limited to detergent-solubilized receptors that can then be reconstituted into a lipid environment. Using the chemokine receptor CXCR4 and its specific ligand CXCL12, we outline here a highly reproducible biosensor method based on receptor presentation on the surface of lentiviral particles; the approach is simple and does not require the use of antibodies to achieve correct receptor orientation on the sensorchip surface. We measured the kinetic parameters of CXCR4/ CXCL12 binding in a single step and in real time and evaluated the effect of GAG presentation of chemokines on this interaction. The data indicate that at low concentrations, soluble heparin modulates CXCR4/ CXCL12 interaction and at high concentrations, abrogates binding. These observations suggest that in addition to their known role in modulating local chemokine availability, GAG affect the receptor/ligand interaction, although their influence on affinity parameters is very limited. The method will also be useful for quantifying these biomarkers in biological fluids and for the development of high-throughput screen-
\end{abstract}

\footnotetext{
Abbreviations: 3D=three-dimensional, EDC=1-ethyl-3-(-3 dimethylaminopropyl) carbodiimide hydrochloride, FISS=Fondo de Investigaciones Sanitarias de la Seguridad Social, GAG=glycosaminoglycans, HEK293=human embryonic kidney cells, $\mathrm{k}_{\mathrm{off}}=$ dissociation constant of the ligand for the receptor, $\mathrm{k}_{\mathrm{on}}=$ association constant of the ligand for the receptor,

Met=methionine, $\mathrm{NHS}=\mathrm{N}$-hydroxysuccinimide, $\mathrm{RT}=$ room temperature, $\mathrm{RU}=$ resonance units, si=small interfering, $\mathrm{SPR}=$ surface plasmon resonance, VSVG=vesicular stomatitis virus $G$
}

The online version of this paper, found at muw.jleukbio.org, includes supplemental information. ing for their antagonists. J. Leukoc. Biol. 90: 000-000; 2011.

\section{Introduction}

A number of genes encode the GPCR, a family of proteins characterized by seven $\alpha$-helical domains that span the cell membrane; these proteins include receptors for hormones, neurotransmitters, chemokines, and calcium ions, among others. The transmembrane-spanning $\alpha$-helices make the receptor extremely hydrophobic, and it requires a lipid environment to maintain its native conformation [1]. The GPCR are thus sensitive to solubilization; detergents can render these proteins nonfunctional, as solubilized receptors undergo conformational changes that alter or impede their ability to bind the ligand [2]. For this reason, ligand-binding analysis and agonist/antagonist screening are done mainly using intact cells.

SPR-based biosensors are established tools for measuring molecular interactions and could thus provide an ideal method to evaluate GPCR-binding interactions [3]. Biosensor experiments involve immobilizing a biomolecule on a sensor surface and monitoring its interaction with a second molecule in solution. SPR biosensors detect association/ dissociation of a biomolecular interaction by measuring changes in the refractive index over the binding surface; binding reactions can thus be evaluated in real time with no labeling requirement [4]. Some attempts have been reported using biosensors to study membrane-associated GPCR; in all these cases, the method is based on capture of detergent-solubilized GPCR prior to their reconstitution in

1. Correspondence: Dept. of Immunology and Oncology, CNB/CSIC, Darwin 3, Cantoblanco, E-28049 Madrid, Spain. E-mail: mmellado@cnb. csic.es 
a lipid environment [5]. These methods require use of detergents and substantial purification prior to analysis. Another important question is receptor capture on the biosensor surface, as uniform receptor orientation on the chip is difficult to achieve in these conditions. Some techniques use a two-step protocol, based on capture of the solubilized receptor with $\mathrm{mAb}$, and reconstitution of a lipid bilayer environment [6]. Although these methods resolve the receptor orientation problem, the element of variability remains a result of detergent solubilization of the receptor [6].

Chemokines are potent chemoattractant cytokines that regulate leukocyte trafficking in homeostatic and inflammatory processes [7]. Depending on their local concentration, which is facilitated by their association to GAG [8], chemokines can recruit circulating leukocytes to a site of inflammation or injury. They act by binding to GPCR; one of these, CXCR4, is also expressed on the surface of various cancer cell types [9]. Mice with gene deletions for CXCR4 or its chemokine ligand, CXCL12, have an identical lethal phenotype, indicating a highly specific receptor/ligand relationship. Mice lacking CXCR4 die perinatally and show defective vascular development, hematopoiesis, and cardiogenesis [10]; CXCL12-deficient mice are characterized by defective B cell lymphopoiesis and myelopoiesis, as well as abnormal neuronal and cardiovascular development [11]. The CXCR4/CXCL12 axis is also implicated in rheumatoid arthritis [12] and pulmonary fibrosis [13]. Finally, together with CCR5, CXCR4 is one the main coreceptors for HIV-1 infection [14].

Using CXCR4 and CXCL12 as a model, we outline a biosensor-based method to determine their binding parameters. Our technique circumvents the limitations of the direct immobilization approach as well as use of detergents. During budding from the cell surface, viruses pull away membrane fragments bearing proteins in their lipid environment; our method takes advantage of this property to present CXCR4 on the surface of lentiviral particles. We found that CXCR4 and probably other receptor types in the context of the cell membrane are incorporated into virions that can be purified easily and attached to the biosensor surface. Binding of specific antibodies and of CXCL12 demonstrated structural integrity of CXCR4 and specificity of the interaction. Other chemokines did not interact, and CXCL12 binding was abrogated by incubation of the lentiviral particles with the CXCR4 antagonist AMD3100 [15]. The use of lentiviral particles allowed us to determine real-time binding parameters for the CXCR4/CXCL12 interaction and to compare the effect on binding of GAG association with chemokines. This approach enables straightforward evaluation of the binding of intact chemokines, their quantification in biological fluids, and high-throughput screening for their antagonists.

\section{MATERIALS AND METHODS}

\section{Cells and reagents}

HEK293T (CRL-11268), HT29 human colon carcinoma cells (HTB-38), and HeLa human cervical adenoma cells (CCL2) were from the American Type Culture Collection (Manassas, VA, USA; CRL-11268). Antibodies were anti-CXCR4-01 [16], -CXCR4 (12G5), and -CXCR4-biotin (12G5, R\&D Sys- tems, Minneapolis, MN, USA); anti-p24 and -VSVG mAb (Abcam, Cambridge, UK); anti-Syndecan-4 mAb (Santa Cruz Biotechnology, Santa Cruz, CA, USA); anti-human CD44-PE (BD Biosciences, San Diego, CA, USA); and anti-CD9 (VJ1/20) mAb (kindly donated by Dr. Francisco SánchezMadrid, Hospital de la Princesa, Madrid, Spain). When needed, we used avidin-PeCy7 (BD Biosciences) and anti-mouse IgG $(\mathrm{H}+\mathrm{L})$ (Southern Biotechnology, Birmingham, AL, USA). Heparan sulfate (H7640), heparin (B9806), chondroitin sulfate (C9819), and AMD3100 were from Sigma-Aldrich (St. Louis, MO, USA); CXCL12, CCL2, and CCL3 were from PeproTech (Rocky Hill, NJ, USA).

\section{siRNA constructs and transfection}

We designed two different siRNA duplexes of CXCR4: siRNA1 (sense, $5^{\prime}$ UAAAAUCUUCCUGCCCACCdTdT-3') and siRNA2 (sense, 5'-GGAAGCUGUUGGCUGAAAAdTdT-3'; Dharmacon, Lafayette, CO, USA). Nonspecific control siRNA duplexes had the same GC content as CXCR4 siRNA (42\%, D001206-10, Dharmacon). HEK293T cells were cultured in RPMI 1640, supplemented with $10 \%$ FBS (both from Sigma-Aldrich) at $37^{\circ} \mathrm{C}$ in $5 \%$ $\mathrm{CO}_{2}$. siRNA were transfected into HEK293T cells at a final concentration of $120 \mathrm{nmol} / \mathrm{L}$ using JetPei (Polyplus, Illkirch, France).

\section{Virion production, purification, and characterization}

Lentiviral particles (X4LP) were produced by JetPei cotransfection of HEK293T cells with the LVTHM, PAX2, and VSVG plasmids (Tronolab, Lausanne, Switzerland) at a 1:1:1 ratio. When necessary, CXCR4 siRNA or CXCR4 was cotransfected with the viral plasmids. At $72 \mathrm{~h}$ post-transfection, the supernatant was harvested and cell debris removed by low-speed centrifugation and $0.45 \mu \mathrm{m}$ filtration, pelleted in a Beckman SW55 rotor $\left(247,000 \mathrm{~g}, 2 \mathrm{~h}, 4^{\circ} \mathrm{C}\right)$ through a $20 \%$ sucrose cushion, and the pellet resuspended in PBS. A second centrifugation step, through a $20-50 \%$ sucrose gradient, was performed in a Beckman SW41 rotor $(281,000 \mathrm{xg}$, $45 \mathrm{~min}$, $\left.4^{\circ} \mathrm{C}\right)$. The fraction with particles was centrifuged $\left(247,000 \mathrm{xg}, 1 \mathrm{~h}, 4^{\circ} \mathrm{C}\right)$ to eliminate sucrose. Finally, lentiviral particles were aliquoted and stored at $-80^{\circ} \mathrm{C}$.

Lentiviral particles were analyzed for VSVG protein, the structural protein p24, and CXCR4 expression by SDS-PAGE and Western blot [16] using specific antibodies and silver staining [17].

Different batches of lentiviral particles were standardized by titration using HEK293T cell transduction. Cells were transduced with twofold serial dilutions of viral particles; after $72 \mathrm{~h}$, GFP expression was analyzed by FACS. Lentiviral particles with a similar titration index were aliquoted and stored at $-80^{\circ} \mathrm{C}$.

\section{Flow cytometry analysis}

HEK293T, HeLa, or HT29 cells were plated in V-bottom 96-well plates $\left(2.5 \times 10^{5}\right.$ cells/well $)$ and incubated $\left(30 \mathrm{~min}, 4^{\circ} \mathrm{C}\right)$ with $10 \mu \mathrm{l} /$ well biotinlabeled anti-CXCR4 mAb $(0.05 \mu \mathrm{g} / \mu \mathrm{l})$, followed by avidin-PECy7 or with $50 \mu \mathrm{l} /$ well PE-labeled anti-human CD44 mAb $(0.01 \mu \mathrm{g} / \mu \mathrm{l})$. Cell-bound fluorescence was determined in a Profile XL flow cytometer $(755 \mathrm{~nm}$, Coulter, Miami, FL, USA).

To evaluate lentiviral particles by flow cytometry, virions were coupled to latex beads. After sonication ( $5 \mathrm{~min}, \mathrm{RT})$, beads $(4 \mu \mathrm{m}, 4 \%$ w/v; A37304, Invitrogen, Eugene, OR, USA) were mixed with lentiviral particles $\left(10^{7} / \mathrm{ml}\right)$ at a $1: 1 \mathrm{v} / \mathrm{v}$ ratio $(15 \mathrm{~min}, \mathrm{RT})$. PBS was added, and the final suspension was incubated $\left(60 \mathrm{~min}, 4^{\circ} \mathrm{C}\right.$, with continuous rocking). The reaction was terminated by adding $100 \mathrm{mM}$ glycine (30 min, RT). Beads coupled to lentiviral particles were washed twice by centrifugation $(3 \mathrm{~min}, 2000 \mathrm{xg}$ ) using washing buffer (PBS/BSA 0.5\%). The pellet was resuspended in washing buffer and stained as above for flow cytometry analysis.

\section{Immunofluorescence analysis}

HEK293T, HT29, or HeLa cells $\left(5 \times 10^{4}\right.$ cells/well) were plated on poly-Llysine-coated coverslips $\left(20 \mu \mathrm{g} / \mathrm{ml}, 1 \mathrm{~h}, 37^{\circ} \mathrm{C}\right.$; Sigma-Aldrich) and cultured 
$\left(24 \mathrm{~h}, 37^{\circ} \mathrm{C}\right)$. Cells were washed in cold PBS and fixed with $4 \%$ paraformaldehyde ( $3 \mathrm{~min}, \mathrm{RT}$ ). To avoid nonspecific binding, cells were treated with PBS, supplemented with $1 \%$ BSA, $0.1 \%$ goat serum, $10 \%$ mouse serum, and $150 \mathrm{mM} \mathrm{NaCl}\left(1 \mathrm{~h}, 37^{\circ} \mathrm{C}\right)$, and then stained with antisyndecan $\mathrm{mAb}$ $\left(0.5 \mu \mathrm{g} / 10^{6}\right.$ cells, $\left.30 \mathrm{~min}, \mathrm{RT}\right)$, followed by Alexa 488-goat anti-mouse IgG (Invitrogen). As a control, cells were stained with anti-CD9 mAb [18], followed by Cy3-goat anti-mouse IgG (Jackson ImmunoResearch, West Grove, PA, USA). Fluorescence was evaluated on a Zeiss Axiovert LSM 510-META inverted microscope with a $63 \times$ oil immersion objective (aperture 1:40) and processed using Image 1.43 software.

\section{ELISAs}

Lentiviral particles ( $10^{7}$ in $100 \mu \mathrm{l}$ PBS) were adsorbed to microtiter plates (Maxisorb, Nunc, Denmark; $90 \mathrm{~min}, 37^{\circ} \mathrm{C}$ ). Remaining protein-binding sites were blocked with $0.5 \%$ BSA in PBS. Plates were washed, incubated with anti-CXCR4 or isotype control mAb $\left(1 \mathrm{~h}, 37^{\circ} \mathrm{C}\right)$, followed by peroxidase-labeled goat anti-mouse IgG (Tago, Burlingame, CA, USA) and o-phenylene diamine (Sigma-Aldrich). The reaction was terminated with $3 \mathrm{~N}$ sulfuric acid and OD determined at $492 \mathrm{~nm}$.

\section{Immunogold detection of virions}

Lentiviral particles were examined by negative-stain EM on carbon grids. Samples were incubated with $30 \mu \mathrm{g} / \mathrm{ml}$ CXCR4-01 antibody in PBS/0.5\% BSA (15 min, RT), followed by a 10-nm gold-conjugated antiIgG + IgM antibody (British Biocell, Cardiff, UK; 15 min, RT). After washing, samples were treated with $2 \%$ uranyl acetate ( 30 s, RT). EM grids were examined in a transmission electron microscope (1200-EX II; Jeol, Tokyo, Japan) at $100 \mathrm{kV}$.

\section{Quantitation of receptor number}

HEK293T cells were transiently cotransfected with plasmids, as indicated above, and incubated in DMEM supplemented with $10 \%$ FCS $\left(24 \mathrm{~h}, 37^{\circ} \mathrm{C}\right.$, $5 \%\left(\mathrm{CO}_{2}\right)$; cells were then washed twice with Met-free DMEM and maintained in this medium supplemented with ${ }^{35} \mathrm{~S}$-Met $\left(50 \mu \mathrm{Ci} / \mathrm{ml}, 48 \mathrm{~h}, 37^{\circ} \mathrm{C}\right.$, $\left.5 \% \mathrm{CO}_{2}\right) \cdot{ }^{35} \mathrm{~S}$-Met-labeled viral particles were collected and purified as above. Samples of the purified particles were used to prepare a doubling dilution series. Identical volumes of these dilutions were loaded onto $12 \%$ polyacrylamide gels, resolved by SDS-PAGE, dried on 3-MM filter paper (Whatman, UK), and visualized by phosphorimaging (Storm 869, Molecular Dynamics, Sunnyvale, CA, USA). Relative CXCR4 stoichiometry within the viral particle was calculated using Quantity One software (BioRad, Hercules, CA, USA) [19]. Intensity of bands corresponding to the structural p24 viral protein and CXCR4-01 antibody was determined and normalized considering the number of Met residues (11 and 6 for p24 and CXCR4, respectively). The relative number of CXCR 4 molecules was calculated by interpolating the intensity values of the sample dilutions onto the regression curve for the p24 data used as an internal standard. The results of three independent experiments indicate that the number of CXCR4 molecules incorporated into the viral envelope corresponded to $\sim 10 \%$ of the number of p24 monomers in the virus core structure; assuming 2100 p24 molecules/virus particle [20], the envelope of our purified lentivirus preparations thus contained an average of $210 \pm 19$ CXCR4 molecules. A similar analysis indicated that lentiviral particles, obtained from CXCR4 transiently transfected HEK293T cells (X4X4LP), had an average of $530 \pm 45$ CXCR4/virion.

\section{Immobilization of lentiviral particles on the sensorchip}

To activate the carboxymethylated dextran, equal volumes of $0.1 \mathrm{M}$ NHS and $0.4 \mathrm{M} \mathrm{EDC}$ were mixed and injected $(5 \mu \mathrm{l} / \mathrm{min}, 7 \mathrm{~min}$, RT) over the surface of a CM5 sensorchip (GE Healthcare, Pittsburgh, PA, USA). Hepesbuffered saline-P [ $10 \mathrm{mM}$ Hepes, $0.15 \mathrm{M} \mathrm{NaCl}, 0.005 \%$ polyoxyethylenesorbitan (P20), $\mathrm{pH}$ 7.4] was used as immobilization running buffer. Lentiviral particles $\left(10^{7} / \mathrm{ml}\right)$ diluted in sodium acetate buffer $(10 \mathrm{mM}, \mathrm{pH} 4.0)$ were injected over the activated surfaces $(5 \mu \mathrm{l} / \mathrm{min}, 7 \mathrm{~min}, \mathrm{RT})$, followed by ethanolamine ( $1 \mathrm{M}, \mathrm{pH} 8.5,5 \mu \mathrm{l} / \mathrm{min}, 7 \mathrm{~min}, \mathrm{RT})$ to deactivate remaining active carboxyl groups. We usually detected $6000 \mathrm{RU}$ coupled lentiviral particles. All determinations were performed using a Biacore 3000 (GE Healthcare).

\section{Kinetic assays on the Biacore}

CXCL12 (25-400 nM), diluted in PBS-P buffer (137 mM NaCl, $10 \mathrm{mM}$ $\mathrm{Na}_{2} \mathrm{HPO}_{4}, 1.76 \mathrm{mM} \mathrm{KH}_{2} \mathrm{PO}_{4}, 2.7 \mathrm{mM} \mathrm{KCl}, 0.005 \% \mathrm{P} 20, \mathrm{pH} 7.4$ ), was injected over the immobilized viral particles $\left(30 \mu \mathrm{l} / \mathrm{min}, 3 \mathrm{~min}, 25^{\circ} \mathrm{C}\right.$; association phase), followed by a 2-min injection period of PBS-P buffer alone over the surface (dissociation phase). Sensorgrams were corrected for signals obtained in the reference flow channel, a control chamber without viral particles, which was activated and deactivated in parallel. All kinetic assays were followed by injection of $5 \mathrm{mM} \mathrm{HCl}$ to dissociate remaining ligand from the virions (regeneration phase). All steps were performed using the system's automated robotics; all phases were followed in real time as a change in signal expressed in RU. Curves derived from these assays were used to generate kinetic constants, which were analyzed by fitting to a simple one-site interaction model with Biaevaluation 4.1 software (Biacore). Alternatively, dissociation constants were derived from the response at equilibrium to corroborate findings from the automated kinetic analyses, although for simplicity, only these last data are included in the manuscript.

When required, CXCL12 was preincubated with different GAG at indicated concentrations $\left(30 \mathrm{~min}, 37^{\circ} \mathrm{C}\right)$ before injection over viral particles as for ligand alone. Signals were corrected as for chemokine alone and for signal produced by injection of uncomplexed GAG over the immobilized virions (control).

\section{Statistical analysis}

Levels of statistical significance among $\mathrm{k}_{\text {on }}, \mathrm{k}_{\text {off }}$, and $K_{\mathrm{D}}$ were calculated by Student's $t$ test (Prism 5.0 software; Prism, Irvine, CA, USA).

\section{Online Supplemental Material}

Supplemental Fig. 1 shows, by immunofluorescence analysis with specific antibodies, that HEK293T cells do not express syndecan-4 proteoglycans at the cell surface. Supplemental Fig. 2 shows by flow cytometry analysis with specific mAb that HEK293T cells do not express CD44 proteoglycans at the cell surface. Supplemental Fig. 3 shows the overlay of the mathematical fittings with the experimental traces corresponding to the kinetic analysis of CXCL12/CXCR4 interactions using X4LP, as well as the overall $\chi^{2}$ value for this fitting.

\section{RESULTS AND DISCUSSION}

\section{Lentiviral particles express CXCR4 at the particle surface}

Flow cytometry analysis using anti-CXCR4 mAb confirmed endogenous CXCR4 expression by HEK293T cells (Fig. 1A). These cells were transiently cotransfected with plasmid LVTHM, PAX2, and VSVG plasmid and supernatant collected at $72 \mathrm{~h}$. After purifying the viral particles (X4LP) on a sucrose gradient, we evaluated CXCR4 in Western blot using the CXCR4-01 mAb (Fig. 1B). Control anti-p24 and -VSVG mAb detected specific bands only in X4LP lysates. The presence of CXCR4 in X4LP was confirmed by ELISA using specific anti-CXCR4 mAb on lentiviral particle-coated plates (Fig. 1C) and by EM techniques with specific antibodies (Fig. 1D). 
A

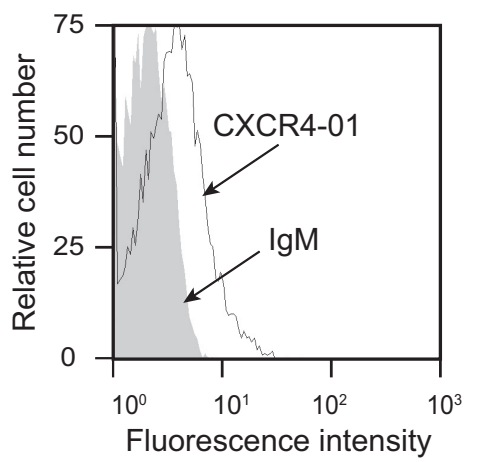

B

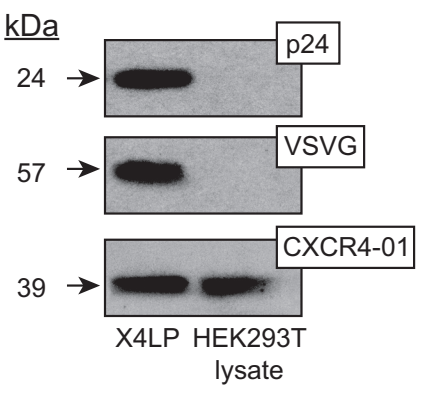

C

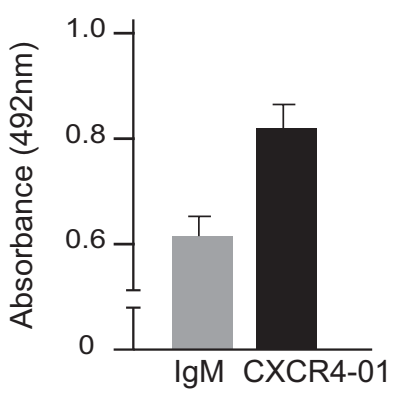

D

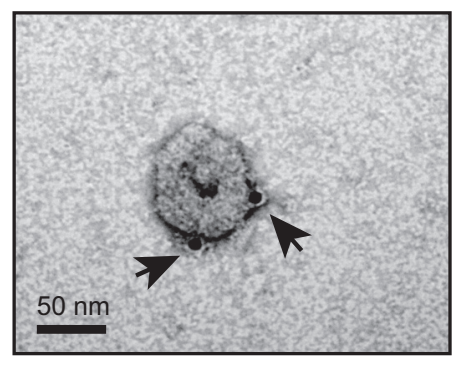

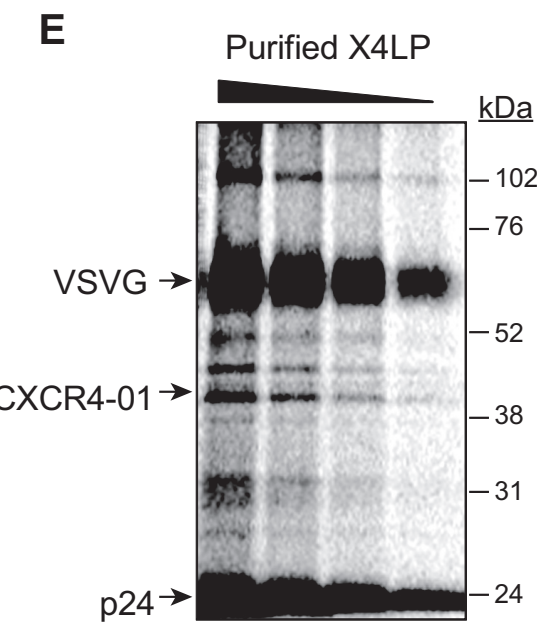

Figure 1. CXCR4 is expressed at the surface of X4LP particles. (A) Membrane expression of CXCR4 in HEK293T cells was analyzed by flow cytometry using specific mAb. One representative experiment is shown of at least three performed. (B) HEK293T and X4LP extracts were analyzed in Western blot with anti-p24, -VSVG, and -CXCR4 mAb. (C) CXCR4 recognition by anti-CXCR4 $\mathrm{mAb}$ in ELISA using X4LP-coated plates. An isotype-matched $\mathrm{mAb}(\operatorname{IgM})$ was used as control. Data represent mean \pm SD of triplicate determinations. (D) Transmission electron micrographs of X4LP particles labeled with anti-CXCR4 $\mathrm{mAb}$ and $10 \mathrm{~nm}$ gold-conjugated anti-IgG + IgM antibody (arrows). Original scale bar $=50 \mathrm{~nm}$. (E) Estimation of the number of CXCR4 molecules in purified X4LP particles. SDS-PAGE and autoradiography of a twofold dilution series from a representative sample of ${ }^{35} \mathrm{~S}$-Met-labeled, purified X4LP. The position of the VSVG, CXCR4, and p24 polypeptides is indicated.

To determine CXCR4 levels in the virions, we transiently transfected HEK293T cells, as above in ${ }^{35}$ S-Met-supplemented medium. After $72 \mathrm{~h}, \mathrm{X} 4 \mathrm{LP}$ particles were collected and purified on sucrose gradients, lysed, and resolved in SDS-PAGE. Bands corresponding to the structural p24 viral protein and CXCR4 were identified by Western blot. The relative amount of ${ }^{35}$ S-Met-labeled CXCR4 was quantified using p24 as standard reference [19]. Based on these results, purified X4LP were estimated to contain an average of 210 CXCR4 molecules/virion (Fig. 1E).

GAG are expressed at the membrane of many cell types [21]. As these polysaccharides also bind chemokines, their presence can interfere with measurement of the binding parameters for the CXCL12/CXCR4 pair. During cell budding, lentiviruses pull away HEK293T cell membrane fragments that contain not only CXCR4 but also other cell components, such as heparan sulfate proteoglycans. As syndecan-4 and CD44 bind chemokines [22, 23], HEK293T cells were stained with antisyndecan $-4 \mathrm{mAb}$ and analyzed by immunofluorescence (Supplemental Fig. 1) or with anti-CD44 and analyzed by FACS (Supplemental Fig. 2). As positive controls, staining of HT29 fibroblasts and HeLa cells was also analyzed. In accordance with previous reports [24, 25] of the possible heparan sulfate proteoglycans, neither synthecan-4 nor CD44 GAG was detected on the surface of HEK293T cells used to prepare lentiviral particles. As control, all cells showed surface expression of CD9 (Supplemental Fig. 1).

\section{X4LP particles bind specifically to CXCL12}

Previous studies using a retroviral, particle-based strategy showed that biosensors can be used successfully to analyze binding of anti-CXCR4 $\mathrm{mAb}$ and to demonstrate association between CXCR4 and the HIV-1 envelope protein gp120 [26]. Moreover, incorporation of CD4 and CCR5 or CXCR4 into viral particles enables them to infect cells expressing gp120 from HIV-1 R5 or X4 viruses [27, 28], indicating that receptor conformation in the virions resembles that on cell membranes. We immobilized X4LP on a CM5 sensorchip (Fig. 2A) and determined anti-CXCR4 mAb binding at a concentration of 30 $\mu \mathrm{g} / \mathrm{ml}$. CXCR4-01 bound X4LP, shown by a steady increase in the SPR signal following the initial bulk-refractive index change during the association phase and by steady dissociation after termination of analyte injection (Fig. 2B). Interaction specificity was corroborated by isotype control $\mathrm{mAb}$, which showed almost no binding (Fig. 2B). Results were similar using the anti-CXCR4 mAb 12G5 (20 $\mu \mathrm{g} / \mathrm{ml}, 30 \mu \mathrm{l} / \mathrm{min}, 3 \mathrm{~min}, \mathrm{RT}$; Fig. 2C). As this antibody recognizes correct CXCR4 folding, the data indicate correct CXCR4 conformation on the virions. The antibody injection gave a fairly low signal (maximum $\sim 120 \mathrm{RU}$ at the end of injection and $\sim 48$ at the beginning of spontaneous dissociation, $30 \mathrm{~s}$ after PBS-P buffer injection). Based on the level of particle immobilization ( $\sim 6000 \mathrm{RU})$, on the estimated MW of the particles $\left(\sim 1.5 \times 10^{8} \mathrm{~g} / \mathrm{mol}\right)$, and on receptor copy number/particle, the maximum theoretical re- 
A
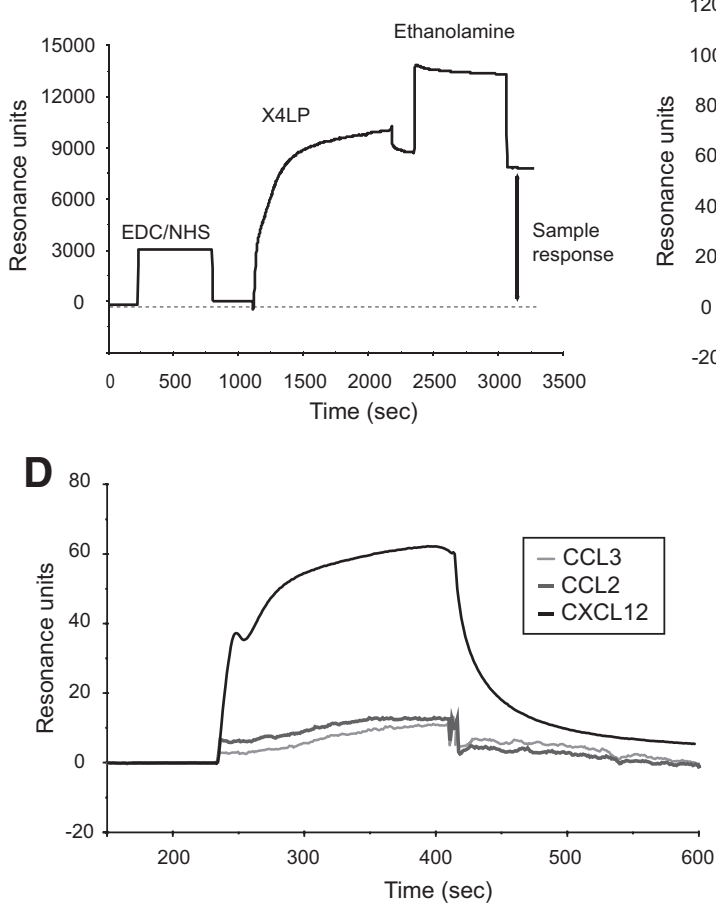

B
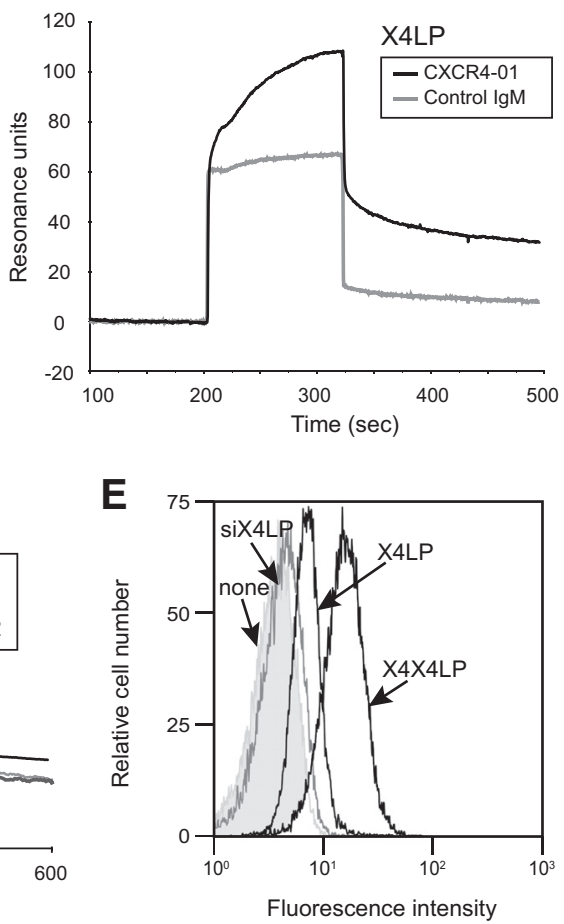

C
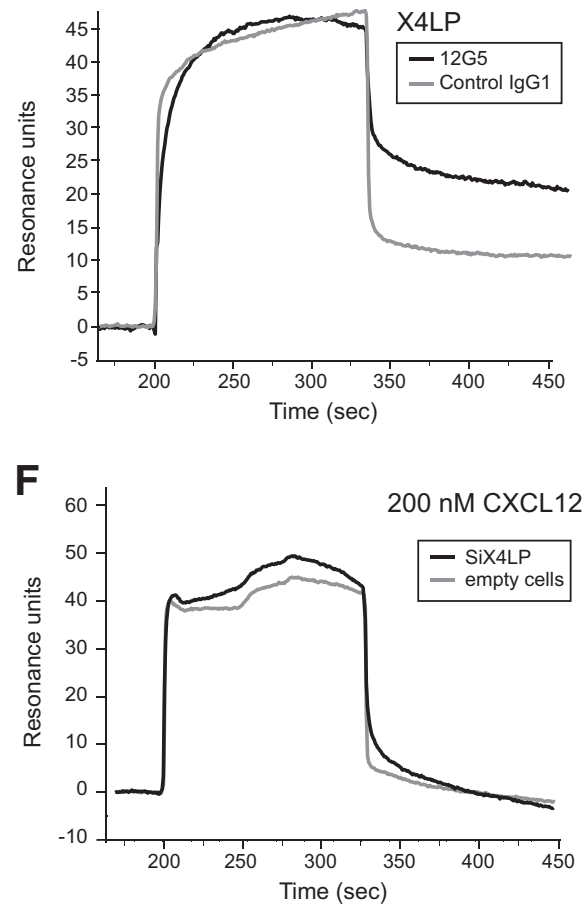

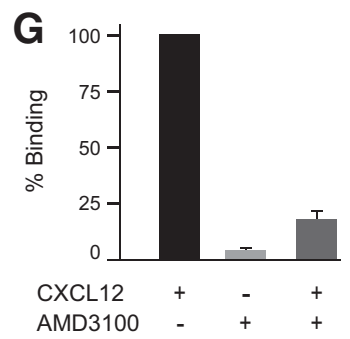

Figure 2. X4LP virions bind CXCL12 specifically. (A) A complete sensorchip activation, X4LP binding, and regeneration cycle on a Biacore 3000 biosensor. (B) Sensorgrams of anti-CXCR4 mAb $(30 \mu \mathrm{g} / \mathrm{ml})$ or isotypematched control binding to the X4LP-coated surface after subtraction of reference sensorchip values. Association was measured for $125 \mathrm{~s}$ and dissociation for $175 \mathrm{~s}$ before regeneration. One representative experiment is shown of at least four performed. (C) Sensorgrams of anti-CXCR4 12G5 mAb (20 $\mu \mathrm{g} / \mathrm{ml})$ or isotype-matched control binding to the X4LP-coated surface as in B. (D) Sensorgrams of CXCL12, CCL2, and CCL3 (all at $200 \mathrm{nM}$ ) binding to the X4LP-coated surface after subtraction of reference sensorchip values. Association was measured for $175 \mathrm{~s}$ and dissociation for $175 \mathrm{~s}$ before regeneration. One representative experiment is shown of at least three performed. (E) Surface expression of CXCR4 in latex bead-coupled siX4LP, X4LP, and X4X4LP, analyzed by flow cytometry using specific mAb and isotype-matched control. One representative experiment is shown of at least four performed. (F) Sensorgrams of CXCL12 (200 nM) binding to the siX4LP-coated surface and to the empty reference sensorchip. Association was measured for $175 \mathrm{~s}$ and dissociation for $125 \mathrm{~s}$ before regeneration. One representative experiment is shown of at least three performed. (G) Effect of AMD3100 pretreatment of the X4LP surface on CXCL12 binding. Maximum RU were obtained for $100 \mathrm{nM}$ CXCL12 binding to untreated or AMD3100-treated X4LP sensorchips; signals for CXCL12 binding to the untreated or treated reference sensorchip have been subtracted. Values as a percentage of maximum binding are the mean \pm SD of five independent experiments.

sponse would be $\sim 600 \mathrm{RU}$. As the particles are immobilized in a $3 \mathrm{D}$ matrix, it is plausible that a fraction of the particle surface is inaccessible to the antibodies. The fact that the $\operatorname{IgM}$ is a large molecule entails a negative-steric effect on the binding of other Ig molecules to neighboring binding sites. To confirm the correct CXCR4 conformation on the viral particles, we evaluated ligand binding. A 200-nM CXCL12 solution was injected onto the X4LP-coated sensorchip; CXCL12 bound $\mathrm{X} 4 \mathrm{LP}$, whereas no interaction was observed in the reference flow cell (Fig. 2D). No binding was detected after control injections of the CCR2-specific ligand CCL2 or the CCR5 ligand CCL3 (both 200 nM; Fig. 2D).

As a specificity control for CXCL12/CXCR4 interactions, lentiviral particles from CXCR4 siRNA transiently transfected HEK293T cells were prepared (siX4LP). Compared with X4LP, siX4LP showed residual levels of CXCR4, as indicated by FACS analysis using anti-CXCR4 mAb (Fig. 2E). CXCL12 solution $(200 \mathrm{nM})$ showed no interaction on siX4LP immobi- lized (6000 RU) on a CM5 sensorchip (Fig. 2F). The sensorgrams were in fact similar to that obtained when the control chamber without viral particles, activated and deactivated in parallel, was used. These results not only confirm signal specificity but also facilitated later analysis, as they allowed the use of the control chamber without viral particles as a reference flow channel.

To verify the chip-regeneration process and determine measurement reproducibility, we repeated 20 cycles of CXCL12 injection and chip regeneration, which showed $<10 \%$ variation in the CXCL12 response. As an additional specificity control, we tested the ability of AMD3100, a small molecule that blocks CXCL12 binding to CXCR4 [15], to modify the CXCL12 signal. AMD3100 $(50 \mu \mathrm{M})$ was injected (5 $\mathrm{\mu l} / \mathrm{min}, 20 \mathrm{~min}, \mathrm{RT})$, followed by a CXCL12 (100 nM) solution containing $50 \mu \mathrm{M}$ AMD3100 (30 $\mu \mathrm{l} / \mathrm{min}, 3 \mathrm{~min}$, $\mathrm{RT})$. There was a clear reduction in CXCL12 binding to $\mathrm{X} 4 \mathrm{LP}$ in the presence of AMD3100 (Fig. 2G). Given the low 
MW of the inhibitor (794.5 daltons) and the fairly low CXCR4 density on the sensorchip, this technique did not permit direct visualization of AMD3100/CXCR4 interactions. Our results indicate that X4LP particles immobilized on the sensorchip bear CXCR4 that binds specifically to its ligand, CXCL12. Other studies used antibodies to retain virus particles on the sensorchip surface [5]; here, particles were covalently attached to activated, carboxymethylated dextran on the sensorchip surface through standard aminecoupling chemistry. Compared with the noncovalent antibody-receptor interaction, the covalent interaction in our immobilization protocol allows multiple regenerations and thus, a larger number of experiments using a single surface. Our 3D particle environment was extremely stable; sensorchip surfaces were regenerated more than 100 times with no appreciable change in particle ability to bind CXCL12 (maximum signal loss $\sim 30 \mathrm{RU}$ ).

\section{Binding parameters of CXCL12 to CXCR4 on X4LP virions}

Real-time SPR biosensor measurements enable direct analysis of interactions between chemokines and their receptors, bypassing the manipulation involved in protein labeling. After confirming specific, reproducible CXCL12 binding to CXCR4expressing X4LP, we analyzed the kinetic parameters of this interaction. Experiments were performed using various batches of viral particles produced over a 2-year period, as well as different sensorchips with multiple repetitions (at least triplicates) on each chip and in two independent laboratories on distinct Biacore instruments, which yielded similar, reproducible results. CXCL12 solutions $(25-400 \mathrm{nM})$ in PBS were injected individually onto sensorchips (30 $\mu \mathrm{l} / \mathrm{min}, 3 \mathrm{~min}, \mathrm{RT})$. After each injection, chips were regenerated with $5 \mathrm{mM} \mathrm{HCl}$. As a reference, solutions were injected in parallel over a flow cell lacking X4LP particles. After subtracting reference flow cell values, we observed maximum response signals in the association phase of $\sim 100 \mathrm{RU}$ and minimum values of $\sim 15 \mathrm{RU}$

(Fig. 3A). Sensorgrams were processed using Biaevaluation 4.1 software, adjusting experimental curves to 1:1 Langmuir-binding models, as no other stoichiometry of CXCL12/CXCR4 binding was predicted, and the demonstrated lack of CXCL12 binding to X4LP particles in the presence of AMD3100 ruled out possible competitive-binding phenomena. The resulting plot of response at equilibrium versus ligand concentration showed a maximum response signal of $\sim 20$ RU (CXCL12, 400 $\mathrm{nM}$ ) and a minimum value of $\sim 7$ RU (CXCL12, $25 \mathrm{nM}$; Fig. 3B). Binding parameter experiments gave similar results when repeated at least four times using different X4LP particles and were, as such, averaged. Binding parameters were $\mathrm{k}_{\text {on }} 4.20 \pm$ $0.56 \times 10^{5} \mathrm{M} \mathrm{s}^{-1} ; \mathrm{k}_{\text {off }} 8.24 \pm 0.11 \times 10^{-3} \mathrm{~s}^{-1}$; and $K_{\mathrm{D}} 3.47 \pm$ $0.05 \times 10^{-8} \mathrm{M}$ (Fig. 3B and Supplemental Fig. 3). Alternatively, a dissociation constant was also established from the response units at equilibrium, corroborating the findings from the mathematical fittings (not shown).

These results correlate with previous data obtained with Scatchard analysis [29-31] and demonstrate the use of this method for evaluating chemokine binding. Our data show higher affinity for chemokine binding than the value ob-
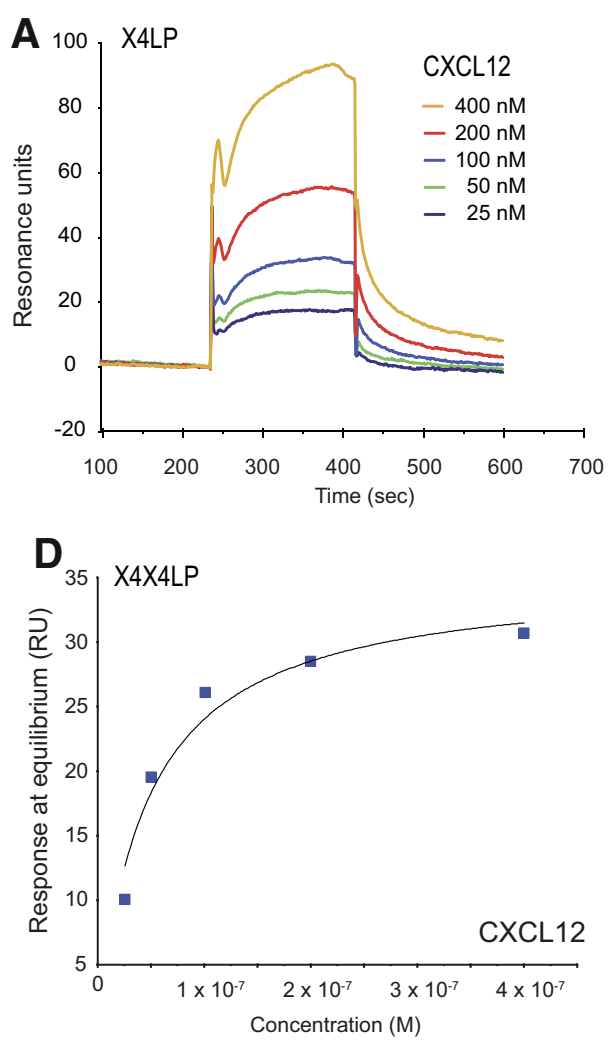
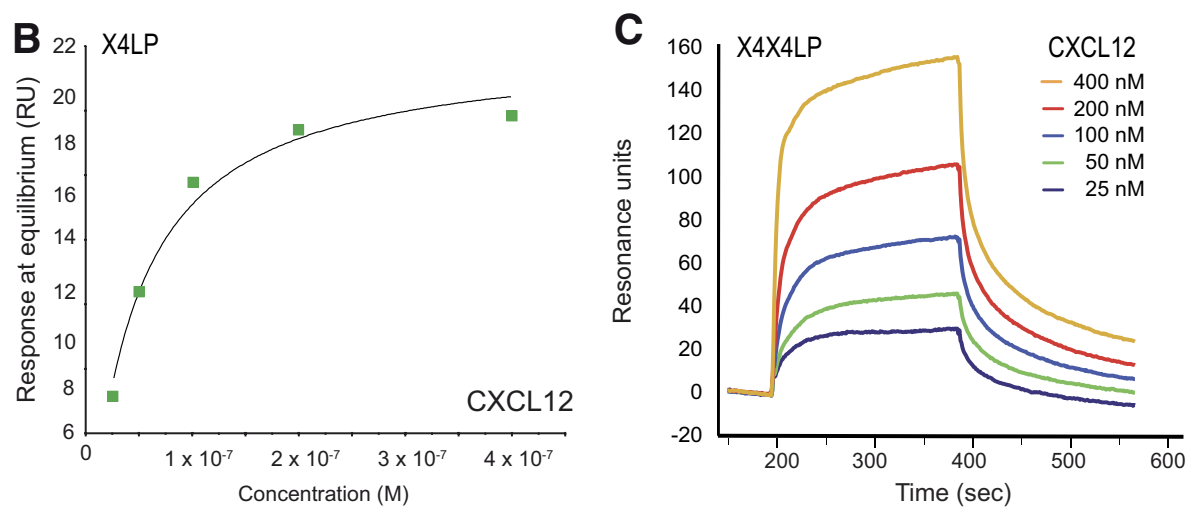

Figure 3. Kinetic analysis of CXCR4/CXCL12 interactions. (A) Sensorgrams for CXCL12 binding (400-25 nM) to X4LP virions immobilized on the sensorchip surface. Aliquots of CXCL12, at distinct concentrations, were injected sequentially into the flow cell, and binding was monitored as RU on the sensorgram. Association was measured for $180 \mathrm{~s}$ and dissociation for $190 \mathrm{~s}$ before regeneration. The binding signal for each CXCL12 concentration to the reference sensorchip was subtracted. One representative experiment is shown of at least four performed. (B) Plot of response at equilibrium versus ligand concentration to fit the kinetic parameters from data in A. (C) Sensorgrams for CXCL12 binding (400-25 nM) to X4X4LP virions immobilized on the sensorchip surface as in A. (D) Plot of response at equilibrium versus ligand concentration to fit the kinetic parameters from data in $\mathrm{C}$. 
tained in the two-step biosensor method (156-180 nM) [6]. This divergence might be a result of the use, in those experiments, of detergent-solubilized CXCR4 immobilized on L1 chips before lipid reconstitution, differences in lipid composition from that of the cell membrane included in the lentiviral particles, lack of specific membrane proteins that modulate ligand binding, or even differences in the conformation adopted by the receptors.

To determine whether intrinsic CXCR4 expression levels influence the kinetic parameters of CXCL12/CXCR4 interactions, CXCR4 transiently transfected HEK293T cells were used to prepare new viral particles (X4X4LP). As predicted, these new particles showed higher CXCR4 levels at the surface, shown by FACS analysis using the CXCR4-01 mAb and viral particle-coated beads (Fig. 2E). For X4X4LP, the number of receptor molecules/virion was determined as $\sim 530$ CXCR4. SPR experiments, using these particles on a CM5 sensorchip at comparable immobilization levels and with CXCL12 solutions (25-400 $\mathrm{nM}, 30 \mu \mathrm{l} / \mathrm{min}, 3 \mathrm{~min}, \mathrm{RT})$, yielded a maximum response in the association phase of $\sim 150 \mathrm{RU}(\sim 30 \mathrm{RU}$ in the response at equilibrium vs. ligand concentration plot) and a minimum of $\sim 20 \mathrm{RU}(\sim 10 \mathrm{RU}$ in the response at equilibrium vs. ligand concentration plot; Fig. 3C and D). Binding parameters were again determined from a minimum of four replicates using different batches of X4X4LP particles; values were $\mathrm{k}_{\text {on }} 3.43 \pm 0.34 \times 10^{5} \mathrm{M}$ $\mathrm{s}^{-1} ; \mathrm{k}_{\text {off }} 13 \pm 0.5 \times 10^{-3} \mathrm{~s}^{-1}$; and $K_{\mathrm{D}} 3.69 \pm 0.18 \times 10^{-8} \mathrm{M}$ (Fig. 3D). Results indicated that CXCR4 levels on virions affected the maximum signal, although not in a linear manner, as a result of the intrinsic $3 \mathrm{D}$ properties of the viral particles (see above), but did not affect kinetic binding parameters. The receptor levels are thus important for establishing the biosensor detection limit and should be considered when the technique will be used in antagonist screenings or to detect these proteins in biological fluids. Our results also indicate that at least in the case of CXCR4, the use of untransfected cells, which facilitates viral particle production, provides a signal sufficient for calculation of binding parameters and that endogenous CXCR4 levels at the cell surface are sufficient to permit CXCL12 detection.

\section{Effect of GAG on CXCL12 binding to CXCR4}

The use of a real-time biomolecular interaction analyzer permits precise measurement of $\mathrm{k}_{\text {on }}$ and $\mathrm{k}_{\text {off }}$ values. These data are of maximum importance for evaluating the effect of other molecules on chemokine receptor/ligand association/dissociation rates. GAG are normally expressed strongly at the cell surface and constitute an extensive network of chemokine binding sites. This binding is functionally important, as it enhances the local chemokine concentration in the vicinity of the receptor and allows formation of chemotactic gradients [32-34]. GAG/chemokine complexes therefore facilitate chemokine/receptor binding [35, 36]. CXCL12 shows affinity for heparin and heparan sulfate $[37,38]$ through interactions based on specific residues on CXCL12 [39].

As the HEK293T cells used here to prepare the lentiviral particles expressed neither syndecan-4 nor CD44 heparan sulfate proteoglycans at the cell surface (Supplemental Figs. 1 and 2), AMD3100 pretreatment of lentiviral particles abrogated the CXCL12 signal, and other chemokines did not associate to virions, binding in our experimental conditions was a result of CXCR4 and not of other lentiviral particle components. This system could thus be used to test the effect of GAG on CXCR4/CXCL12 binding. We incubated CXCL12 (200 nM, $30 \mathrm{~min}, 37^{\circ} \mathrm{C}$ ) with increasing concentrations of heparin or heparan sulfate $(7.8 \mathrm{ng} / \mathrm{ml}-4 \mu \mathrm{g} / \mathrm{ml})$, and solutions were injected $(30 \mu \mathrm{l} / \mathrm{min}, 3 \mathrm{~min}, \mathrm{RT})$ into sensor flow cells alone or with virions. The signal triggered by injection of heparin or heparan sulfate alone into X4LPcontaining chambers was subtracted to establish the specific signal of GAG/CXCL12 complexes on CXCR4. Low heparin concentrations complexed with CXCL12 did not modify the signal for CXCL12 alone ( $~ 90 \mathrm{RU}$ for $7.8 \mathrm{ng} / \mathrm{ml}$ ), but heparin concentrations $\geq 1 \mu \mathrm{g} / \mathrm{ml}$ reduced CXCL12 binding to CXCR4 (Fig. 4A); results were similar for heparan sulfate complexes (not shown). These data concur with reports that high concentrations of soluble GAG compete with chemokine/chemokine receptor binding [40]. These observations contrast with reports showing clear structural separation between the CXCL12 domains involved in receptor $(\mathrm{N}$ loop) and GAG binding ( $\beta 1$ and $\beta 2$ strands) [38, 41]. Nuclear magnetic resonance spectroscopy and X-ray crystallography analyses showed two CXCL12 structural domains for heparin or heparan sulfate binding: one corresponding to the $\beta$-strands at the dimer interface and the second in the motif involved in receptor binding, that is, the N-terminal and $\alpha$-helix region [42]; these findings clarify the inhibitory effect of high GAG concentrations on CXCR4/CXCL12 binding. High GAG concentrations block the CXCL12 N-terminal domain, inhibiting CXCR4/ CXCL12 binding. The N-terminal domain is unaffected at low GAG concentrations, allowing CXCL12:receptor binding. Our results are also consistent with results using ${ }^{125} \mathrm{I}-$ CXCL8 and ${ }^{125}$ I-CCL3 with CXCR1-, CXCR2-, or CCR1transfected CHO cell membranes [36], as well as with data from various laboratories showing that soluble heparin and heparan sulfate inhibit leukocyte responses [40, 42]. Unfractionated heparin and the low MW heparin Tinzaparin inhibit CXCL12 binding to CXCR4-expressing CHO cells and human breast cancer cell lines, thus blocking signaling; these compounds might be useful in preventing chemokinedriven breast cancer metastasis [43].

Our findings show that only certain GAG (heparin and heparan sulfate but not chondroitin sulfate) affect CXCR4/ CXCL12 binding. We have nonetheless observed that independently of the GAG concentration used, there was a weak effect on binding when CXCL12 was coinjected with the nonspecific GAG chondroitin sulfate A (Fig. 4B). At high heparin or heparan sulfate concentrations, the GAG/ CXCL12 complex interfered with chemokine binding to its receptor by blocking of the CXCL12 N-terminal region, as shown by structural studies [38]. Moreover, the reduced impact of GAG on the SPR readout yielded nearly overlapping sensorgrams in the association and dissociation phases (Fig. 4). At a threshold GAG concentration (500 $\mathrm{ng} / \mathrm{ml}$ in our 
Figure 4. Effect of GAG on CXCL12 binding to CXCR4.

(A) Sensorgrams of $200 \mathrm{nM}$ CXCL12 binding, alone or incubated with increasing concentrations of heparin $(7.8 \mathrm{ng} / \mathrm{ml}-4 \mu \mathrm{g} /$ $\mathrm{ml}$ ), to the X4LP-coated surface. Individual signals were subtracted for CXCL12 and for heparin binding to the reference sensorchip and for heparin binding to the X4LP-coated surface. Association was measured for $180 \mathrm{~s}$ and dissociation for $325 \mathrm{~s}$ before regeneration (left). From these values, we subtracted the signal for CXCL12 (200 nM) binding to the X4LPcoated surface (right). One representative experiment is shown of at least four performed. (B) Sensorgrams of $200 \mathrm{nM}$ CXCL12 binding, alone or incubated with increasing concentrations of chondroitin sulfate A $(125 \mathrm{ng} / \mathrm{ml}-4$ $\mu \mathrm{g} / \mathrm{ml}$ ), to the X4LP-coated surface. Individual signals were subtracted for CXCL12 and for chondroitin sulfate A binding to the reference sensorchip and for chondroitin sulfate A binding to the X4LP-coated surface. Association and dissociation were measured as in A before regeneration (left); from these values, the CXCL12 signal was subtracted as in A (right). One representative experiment is shown of at least four performed. (C) Sensorgrams for heparin/CXCL12 complex binding at a 1:384 ratio to X4LP virions immobilized on the sensorchip surface. Aliquots of heparin/CXCL12 complexes at indicated concentrations were injected sequentially into the flow cell and binding monitored in RU on the sensorgram. Association was measured for $180 \mathrm{~s}$ and dissociation for $185 \mathrm{~s}$ before regeneration. Heparin/CXCL12 binding signal to the reference sensorchip was subtracted. One representative experiment is shown of at least four performed.
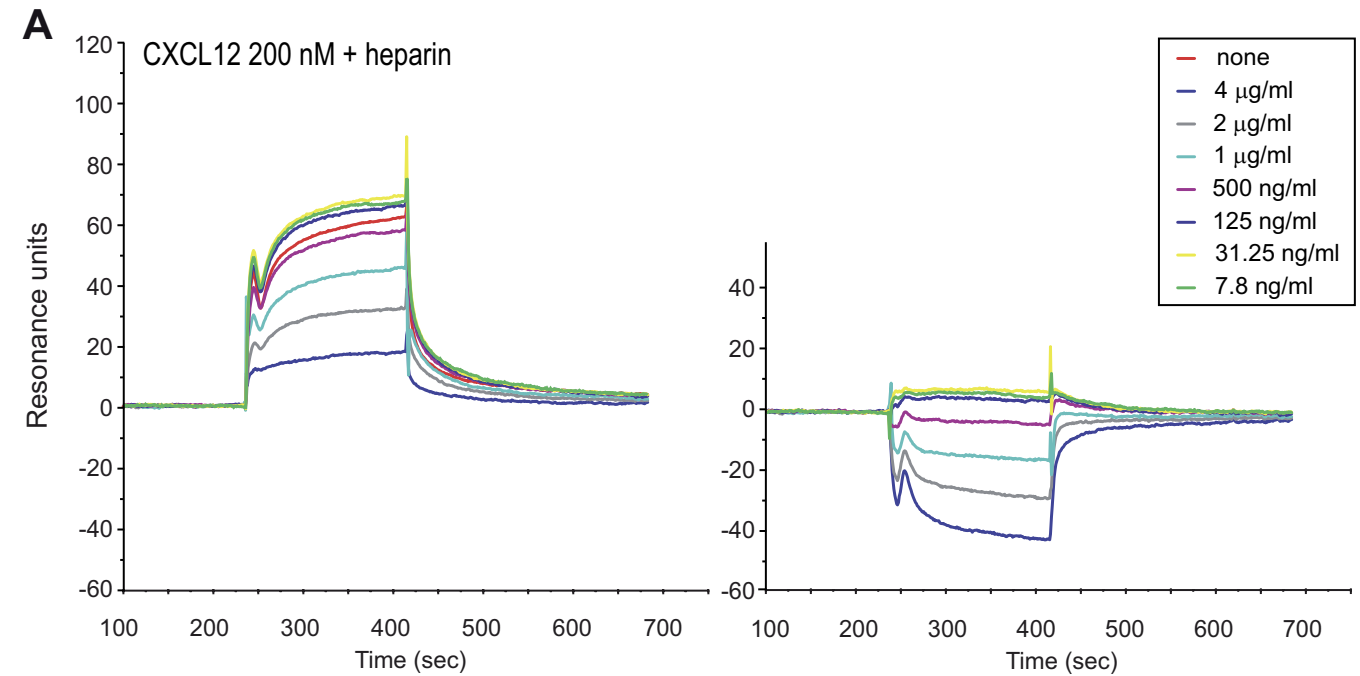

B
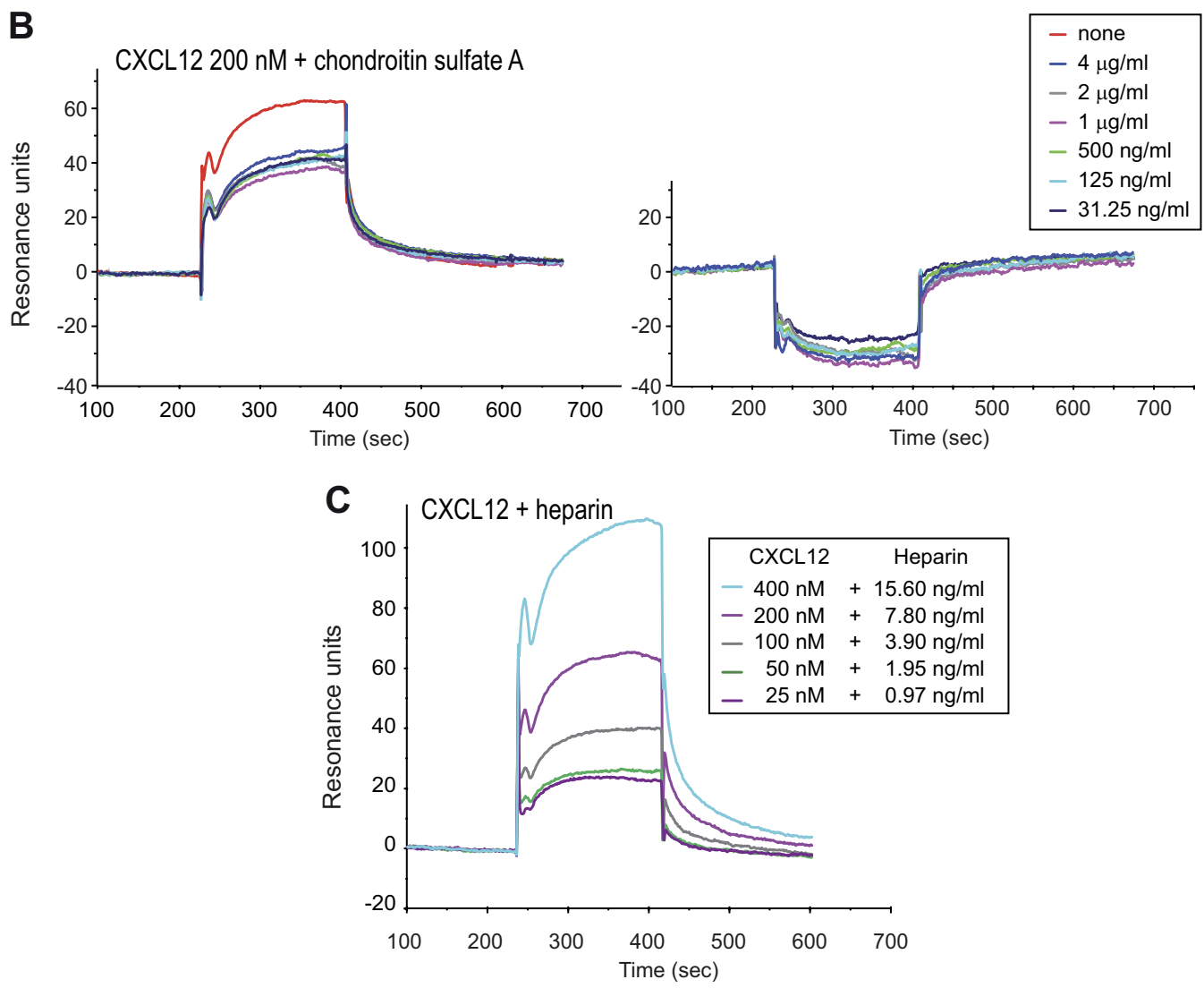

SPR conditions), GAG interference is not evident in the dissociation phase but is detected as a lower association curve; this phenomenon is unambiguous in association and dissociation curves at GAG concentrations $\geq 1 \mu \mathrm{g} / \mathrm{ml}$. GAG interference is best visualized in the SPR experiments when the contribution of individual sample components (GAG, CXCL12) is subtracted from sensorgrams (Fig. 4A, right), allowing definition of the threshold concentration (at which the dissociation phase shows a null response, indicating lack of residual binding after termination of analyte injection).
Based on these data, we used a heparin:chemokine complex $(7.8 \mathrm{ng} / \mathrm{ml}$ heparin and $200 \mathrm{nM}$ CXCL12) to evaluate binding, which allowed maximum binding to the receptor with no interference compared with chemokine alone.

Solutions of increasing heparin/CXCL12 concentrations at a constant ratio $(7.8 \mathrm{ng} / \mathrm{ml} / 200 \mathrm{nM})$ were injected into $\mathrm{X} 4 \mathrm{LP}$ and control flow cells $(30 \mu \mathrm{l} / \mathrm{min}, 3 \mathrm{~min}$, RT). Sensorchip surfaces were regenerated with $5 \mathrm{mM} \mathrm{HCl}$. Maximum- and minimum-specific responses were $\sim 100 \mathrm{RU}$ and $\sim 20$ RU for the association phases (Fig. 4C). Sensorgrams 
processed as above showed that binding parameters differed from those for CXCL12 alone $\left(\mathrm{k}_{\text {on }} 5.49 \pm 0.14 \times 10^{5} \mathrm{M} \mathrm{s}^{-1}\right.$; $\mathrm{k}_{\text {off }} 1.63 \pm 0.10 \times 10^{-3} \mathrm{~s}^{-1} ; K_{\mathrm{D}} 6.67 \pm 0.01 \times 10^{-8} \mathrm{M}$; Fig. 4C). These data indicate that heparin not only modulated CXCL12 availability in the medium but also significantly reduced CXCL12 affinity for CXCR4 binding $\left(3.47 \pm 0.05 \times 10^{-8} \mathrm{M}\right.$ for CXCL12 alone; $6.67 \pm 0.01 \times 10^{-8} \mathrm{M}$ for the heparin/ CXCL12 complex; $P \leq 0.01)$. Differences are attributed to a higher dissociation rate for heparin/CXCL12 complexes $\left(8.24 \pm 0.11 \times 10^{-3} \mathrm{~s}^{-1}\right.$ for CXCL12 alone; $1.63 \pm 0.10 \times 10^{-3} \mathrm{~s}^{-1}$ for complexes; $P \leq 0.001)$. Although statistically significant, the narrow margin between the $K_{\mathrm{D}}$ and $\mathrm{k}_{\text {off }}$ values for the chemokine alone or in complex with heparin nonetheless suggests limited influence of these parameters on the biology of these inflammatory mediators.

The use of lentiviral particles to present cell membrane proteins allows detailed study of ligand interactions using optical biosensors in conditions that resemble the in vivo situation, lipid composition of the cell membrane, receptor conformations, and presence of other proteins that modulate binding parameters. The approach has clear use for drug discovery research, as it facilitates screening for agonist/antagonist effects and simplifies biomarker detection in biological fluids.

\section{AUTHORSHIP}

L.M.M., R.G-G., and M.M. conceived of and designed the experiments; B.V., B.L.H., P.L., A.C., J.L.R-F., and J.M.R-F. performed experiments; L.M.L., R.G-G., and J.F.R. contributed a novel technique; and M.M. wrote the manuscript.

\section{ACKNOWLEDGMENTS}

B.V. is supported by a fellowship from the Spanish Ministry of Health FISS. This work was supported in part by grants from the Spanish Ministry of Science and Innovation (SAF 200803388; SAF 2008-00908), the FISS (RD08/0075/0010), and the European Union (Innochem LSHB-CT-2005-518167 and FP7 Integrated Project Masterswitch 223404). We thank Drs. J. M. Casasnovas and C. Santiago from the Macromolecular Structures Department, Centro Nacional de Biotecnología/Consejo Superior de Investigaciones Cientificas, for technical support. We also thank C. Bastos and C. Mark for secretarial and editorial assistance, respectively.

\section{REFERENCES}

1. Yoshiura, C., Kofuku, Y., Ueda, T., Mase, Y., Yokogawa, M., Osawa, M., Terashima, Y., Matsushima, K., Shimada, I. (2010) NMR analyses of the interaction between CCR5 and its ligand using functional reconstitution of CCR5 in lipid bilayers. J. Am. Chem. Soc. 132, 6768-6777.

2. Ren, H., Yu, D., Ge, B., Cook, B., Xu, Z., Zhang, S. (2009) High-level production, solubilization and purification of synthetic human GPCR chemokine receptors CCR5, CCR3, CXCR4 and CX3CR1. PLoS ONE 4, e4509.

3. Rich, R. L., Myszka, D. G. (2000) Advances in surface plasmon resonance biosensor analysis. Curr. Opin. Biotechnol. 11, 54-61.

4. Dalvit, C. (2009) NMR methods in fragment screening: theory and a comparison with other biophysical techniques. Drug Discov. Today 14, 1051-1057.
5. Navratilova, I., Sodroski, J., Myszka, D. G. (2005) Solubilization, stabilization, and purification of chemokine receptors using biosensor technology. Anal. Biochem. 339, 271-281.

6. Stenlund, P., Babcock, G. J., Sodroski, J., Myszka, D. G. (2003) Capture and reconstitution of G-protein-couple receptors on a biosensor surface. Anal. Biochem. 316, 243-250.

7. Gerard, C., Rollins, B. J. (2001) Chemokines and disease. Nat. Immunol. 2, 108-115.

8. Handel, T. M., Johnson, Z., Crown, S. E., Lau, E. K., Proudfoot, A. E. (2005) Regulation of protein function by glycosaminoglycans as exemplified by chemokines. Annu. Rev. Biochem. 74, 385-410.

9. Burger, J. A., Kipps, T. J. (2006) CXCR4: a key receptor in the crosstalk between tumor cells and their microenvironment. Blood 107, 1761-1767.

10. Tachibana, K., Hirota, S., Iizasa, H., Yoshida, H., Kawabata, K., Kataoka, Y., Kitamura, Y., Matsushima, K., Yoshida, N., Nishikawa, S., Kishimoto, T., Nagasawa, T. (1998) The chemokine CXCR4 is essential for vascularization of the gastrointestinal tract. Nature 393, 591-594.

11. Nagasawa, T., Hirota, S., Tachibana, K., Takakura, N., Nishikawa, S., Kitamura, Y., Yoshida, N., Kikutani, H., Kishimoto, T. (1996) Defects of B-cell lymphopoiesis and bone-marrow myelopoiesis in mice lacking the CXC chemokine PBSF/SDF-1. Nature 382, 635-638.

12. Nanki, T., Takada, K., Komano, Y., Morio, T., Kanegane, H., Nakajima, A., Lipsky, P. E., Miyasaka, N. (2009) Chemokine receptor expression and functional effects of chemokines on B cells: implication in the pathogenesis of rheumatoid arthritis. Arthritis Res. Ther. 11, R149.

13. Xu, J., Mora, A., Shim, H., Stecenko, A., Brigham, K. L., Rojas, M. (2007) Role of the SDF/CXCR4 axis in the pathogenesis of lung injury and fibrosis. Am. J. Respir. Cell Mol. Biol. 37, 291-299.

14. Berger, E. A., Murphy, P. M., Farber, J. M. A. (1999) Chemokine receptors as HIV-1 coreceptors: roles in viral entry, tropism, and disease. Annu. Rev. Immunol. 17, 657-700.

15. De Clercq, E. (2003) The bicyclam AMD3100 story. Nat. Rev. Drug Discov. 2, 581-587.

16. Vila-Coro, A. J., Rodríguez-Frade, J. M., Martín De Ana, A., Moreno-Ortíz M. C., Martínez-A, C., Mellado, M. (1999) The chemokine SDF-1 $\alpha$ triggers CXCR4 dimerization and actives the JAK/STAT pathway. FASEB J. 13, 1699-1710

17. Weiss, W., Weiland, F., Görg, A. (2009) Protein detection and quantitation technologies for gel-based proteome analysis. Methods Mol. Biol. 564, $59-82$.

18. Longo, N., Yáñez-Mó, M., Mittelbrunn, M., de la Rosa, G., Muñoz, M-L., Sánchez-Madrid, F., Sánchez-Mateos, P. (2001) Regulatory role of tetraspanin CD9 in tumor-endothelial cell interaction during transendothelia invasion of melanoma cells. Blood 98, 3717-3726.

19. Luque, D., Rivas, G., Alfonso, C., Carrascosa, J. L., Rodríguez, J. F., Castón, J. R. (2009) Infectious bursal disease virus is an icosahedral polyploidy dsRNA virus. Proc. Natl. Acad. Sci. USA 106, 2148-2152.

20. Briggs, J. A. G., Wilk, T., Welker, R., Krausslich, H-G., Fuller, S. D. (2003) Structural organization of authentic, mature HIV-1 virions and cores. EMBO J. 22, 1707-1715.

21. Middleton, J., Patterson, A. M., Gardner, L., Schmutz, C., Ashton, B. A. (2002) Leukocyte extravasation: chemokine transport and presentation by the endothelium. Blood 100, 3853-3860.

22. Hamon, M., Mbemba, E., Charnaux, N., Slimani, H., Brule, S., Saffar, L., Vassy, R., Prost, C., Lievre, N., Starzec, A., Gattegno, L. (2004) A syndecan-4/CXCR4 complex expressed on human primary lymphocytes and macrophages and HeLa cell line binds the CXC chemokine stromal cellderived factor-1 (SDF-1). Glycobiology 14, 311-323.

23. Roscic-Mrkic, B., Fischer, M., Leemann, C., Manrique, A., Gordon, C. J., Moore, J. P., Proudfoot, A. E., Trkola, A. (2003) RANTES (CCL5) uses the proteoglycan CD44 as an auxiliary receptor to mediate cellular activation signals and HIV-1 enhancement. Blood 102, $1169-1177$.

24. Matsuura, H., Momota, Y., Murata, K., Matsushima, H., Suzuki, N., Nomizu, M., Shinkai, H., Utani, A. (2004) Localization of the laminin $\alpha 4$ chain in the skin and identification of a heparin-dependent cell adhesion site within the laminin $\alpha 4$ chain C-terminal LG4 module. J. Invest. Dermatol. 122, 614-620.

25. Harada, H., Takahashi, M. (2007) CD44-dependent intracellular and extracellular catabolism of hyaluronic acid by hyaluronidase-1 and -2. J. Biol. Chem. 282, 5597-5607.

26. Hoffman, T. L., Canziani, G., Jia, L., Rucker, J., Doms, R. W. (2000) A biosensor assay for studying ligand-membrane receptor interactions: binding of antibodies and HIV-1 Env on chemokine receptors. Proc. Natl. Acad. Sci. USA 97, 11215-11220.

27. Endres, M. J., Jaffer, S., Haggarty, B., Turner, J. D., Doranz, B. J., O'Brien, P. J., Kolson, D. L., Hoxie, J. A. (1997) Targeting of HIV- and SIV-infected cells by SD4-chemokine receptor pseudotypes. Science 278, 1462-1464.

28. Schnell, M. J., Johnson, J. E., Buonocore, L., Rose, J. K. (1997) Construction of a novel virus that targets HIV-1-infected cells and controls HIV-1 infection. Cell 90, 849-857.

29. Laguri, C., Sadir, R., Rueda, P., Baleux, F., Gans, P., Arenzana-Seisdedos, F., Lortat-Jacob, H. (2007) The novel CXCL12 $\gamma$ isoform encodes 
an unstructured cationic domain which regulates bioactivity and interaction with both glycosamiglycans and CXCR4. PLoS ONE 2, e1110.

30. Di Salvo, J., Koch, G. E., Johnson, K. E., Blake, A. D., Daugherty, B. L. DeMartino, J. A., Sirotina-Meisher, A., Liu, Y., Springer, M. S., Cascieri, M. A., Sullivan, K. A. (2000) The CXCR4 agonist ligand stromal derived factor-1 maintains high affinity for receptors in both $\mathrm{G} \alpha(\mathrm{i})$-coupled and uncoupled states. Eur. J. Pharmacol. 409, 143-154.

31. Lechertier, T., Berard, M., Vassy, R., Herve, M. A., Crepin, M. (2004) Transendothelial migration of two metastatic breast carcinoma cells depend on the SDF-1 $\alpha$-CXCR4 complexes. Anticancer Res. 24, 40114017.

32. Tanaka, Y., Adams, D. H., Shaw, S. (1993) Proteoglycans on endothelial cells present adhesion-inducing cytokines to leukocytes. Immunol. Today 14, 111-115.

33. Hoogewerf, A. J., Kuschert, G. S., Proudfoot, A. E., Borlat, F., ClarkLewis, I., Power, C. A., Wells, T. N. (1997) Glycosamiglycans mediate cell surface oligomerization of chemokines. Biochemistry 36, 1357013578

34. Friand, V., Haddad, O., Papy-Garcia, D., Hlawaty, H., Vassy, R., HammaKourbali, Y., Perret, G. Y., Courty, J., Baleux, F., Oudar, O., Gattegno, L., Sutton, A., Charnaux, N. (2009) Glycosamiglycan mimetics inhibit SDF1/CXCL12-mediated migration and invasion of human hepatoma cells. Glycobiology 19, 1511-1524.

35. Johnson, Z., Proudfoot, A. E., Handel, T. M. (2005) Interaction of chemokines and glycosaminoglycans: a new twist in the regulation of chemokine function with opportunities for therapeutic intervention. Cytokine Growth Factor Rev. 16, 625-636.

36. Charnaux, N., Brule, S., Chaigneau, T., Saffar, L., Sutton, A., Hamon, M., Prost, C., Lievre, N., Vita, C., Gattegno, L. (2005) RANTES (CCL5) induces a CCR5-dependent accelerated shedding of syndecan-1 (CD138) and syndecan- 4 from HeLa cells and forms complexes with the shed ectodomains of these proteoglycans as well as with those of CD44. Glycobiology 15, 119-130.
37. Bleul, C. C., Fuhlbrigge, R. C., Casasnovas, J. M., Aiuti, A., Springer, T. A. (1996) A highly efficacious lymphocyte chemoattractant, stromal cell-derived factor 1(SDF-1). J. Exp. Med. 184, 1101-1109.

38. Sadir, R., Baleux, F., Grosdidier, A., Imberty, A., Lortat-Jacob, H. (2001) Characterization of the stromal cell-derived factor- $1 \alpha$-heparin complex. J. Biol. Chem. 276, 8288-8296.

39. Amara, A., Lorthioir, O., Valenzuela, A., Magerus, A., Thelen, M., Montes, M., Virelizier, J. L., Delepierre, M., Baleux, F., Lortat-Jacob, H., Arenzana-Seisdedos, F. (1999) Stromal cell-derived factor-1 $\alpha$ associates with heparan sulfates through the first $\beta$-strand of the chemokine. J. Biol. Chem. 274, 23916-23925.

40. Kuschert, G. S., Coulin, F., Power, C. A., Proudfoot, A. E., Hubbard, R. E., Hoogewerf, A. J., Wells, T. N. (1999) Glycosaminoglycans interact selectively with chemokines and module receptor binding and cellular responses. Biochemistry 38, 12959-12968.

41. Laguri, C., Arenzana-Seisdedos, F., Lortat-Jacob, H. (2008) Relationships between glycosaminoglycan and receptor binding sites in chemokinesthe CXCL12 example. Carbohydr. Res. 343, 2018-2023.

42. Murphy, J. W., Cho, Y., Sachpatzidis, A., Fan, C., Hodsdon, M. E., Lolis, E. (2007) Structural and functional basis of CXCL12 (stromal cellderived factor-1 $\alpha$ ) binding to heparin. J. Biol. Chem. 282, 1001810027.

43. Harvey, J. R., Mellor, P., Eldaly, H., Lennard, T. W., Kirby, J. A., Ali, S. (2007) Inhibition of CXCR4-mediated breast cancer metastasis: a potential role for heparinoids? Clin. Cancer Res. 13, 1562-1570.

\section{KEY WORDS:}

chemokine $\cdot$ biosensor $\cdot$ glycosaminoglycan $\cdot$ affinity constant

- chemokine receptor 